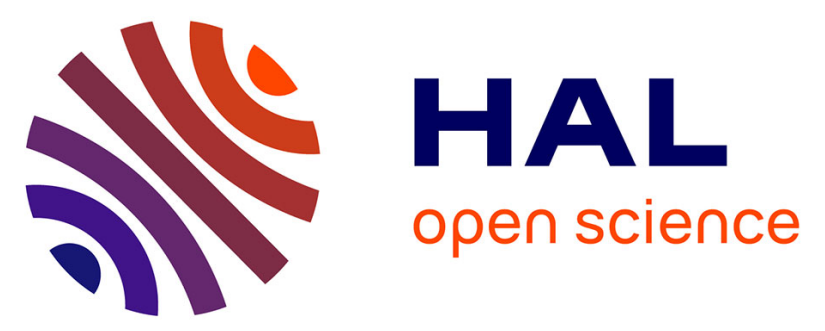

\title{
Deciphering the structural and metamorphic history of the Balsfjord Series in the Upper Allochthon of the Scandinavian Caledonides in northern Norway
} Stephan Höpfl, Jiří Konopásek, Holger Stünitz, Steffen G. Bergh

\section{- To cite this version:}

Stephan Höpfl, Jiř́ Konopásek, Holger Stünitz, Steffen G. Bergh. Deciphering the structural and metamorphic history of the Balsfjord Series in the Upper Allochthon of the Scandinavian Caledonides in northern Norway. vEGU21: Gather Online, Apr 2021, Online, France. 10.5194/egusphere-egu217179 . hal-03554563

\author{
HAL Id: hal-03554563 \\ https://hal.science/hal-03554563
}

Submitted on 3 Feb 2022

HAL is a multi-disciplinary open access archive for the deposit and dissemination of scientific research documents, whether they are published or not. The documents may come from teaching and research institutions in France or abroad, or from public or private research centers.
L'archive ouverte pluridisciplinaire HAL, est destinée au dépôt et à la diffusion de documents scientifiques de niveau recherche, publiés ou non, émanant des établissements d'enseignement et de recherche français ou étrangers, des laboratoires publics ou privés. 


\title{
EGU21-7179
}

https://doi.org/10.5194/egusphere-egu21-7179

EGU General Assembly 2021

(c) Author(s) 2022. This work is distributed under

the Creative Commons Attribution 4.0 License.

\section{Deciphering the structural and metamorphic history of the Balsfjord Series in the Upper Allochthon of the Scandinavian Caledonides in northern Norway}

\author{
Stephan Höpfl ${ }^{1}$, Jiří Konopásek ${ }^{1}$, Holger Stünitz ${ }^{1,2}$, and Steffen G. Bergh ${ }^{1}$ \\ ${ }^{1}$ UiT Norges arktiske universitet, Modulbygget - Framstredet 10, 9019 Tromsø, Norway, Institutt for geovitenskap, Troms $\emptyset$, \\ Norway (stephan.m.hopfl@uit.no) \\ ${ }^{2}$ Institut des Sciences de la Terre (ISTO), Université d'Orleans, Orleans 45100, France
}

Deciphering the structural and metamorphic history of the Balsfjord Series in the Upper Allochthon of the Scandinavian Caledonides in northern Norway

Höpfl Stephan ${ }^{1}$, Konopásek Jiř́ ${ }^{1}$, Stünitz Holger ${ }^{1,2}$ Bergh G., Steffen ${ }^{1}$

UiT Norges arktiske universitet, Institutt for geovitenskap, stephan.m.hopfl@uit.no

${ }^{1}$ Department of Geosciences, UiT The Arctic University of Norway, Tromsø 9037, Norway

${ }^{2}$ Institut des Sciences de la Terre (ISTO), Université d'Orleans, Orleans 45100, France

The Balsfjord Series is located in the central part of Troms-Finnmark County, northern Norway, and is part of the upper allochthon of the Scandinavian Caledonides. It consists of an Ordovician-Silurian metsedimentary sequence lying on top of the mostly gabbroic Lyngen Magmatic Complex (LMC). The unit exhibits an inverted metamorphic gradient, where the metamorphic conditions increase from the base to the top, from very low grade in the southeast to medium grade in the west and northwest. The Balsfjord Series is sandwiched between two highgrade units, the Nakkedal + Tromsø Nappe Complex in the hanging wall and the Nordmannvik Nappe as the top part of the Reisa Nappe Complex (RNC) in the footwall. The Nakkedal + Troms $\varnothing$ Nappe Complex features metamorphic peak ages of ca. 455-450 Ma and the Nordmannvik Nappe of ca. $430 \mathrm{Ma}$. The peak metamorphism of the Balsfjord Series has never been dated and the role of the inverted metamorphic gradient is not yet understood. One of the main motivations in this project is to resolve the Caledonian deformation history in the Balsfjord Series, ideally leading to a regional tectonic model explaining the tectonostratigraphic and metamorphic relationships between the abovementioned units.

The Balsfjord Series features two main discernible folding phases. The earlier phase displays tight 
to isoclinal folds with flat lying axial surfaces parallel to the penetrative foliation. Observed fold axes are parallel with the stretching lineation. These folds are best preserved in the northwestern, upper part of the unit and are syn-metamorphic in certain areas, as they fold original bedding (transposed foliation). A later folding phase is represented by mainly open folds with inclined to steep axial surfaces. Their fold axes are gently plunging with a predominant NE-SW orientation. We interpret these two folding events to be genetically related but slightly diachronous. The earlier folding phase with flat lying axial surfaces was likely generated during nappe thrusting and peak metamorphism of the Balsfjord Series. The subsequent open folding with inclined to steep axial surfaces is explained as a result of continued shearing and shortening of the weaker metapelitic Balsfjord Series against the more rigid gabbroic part of the LMC during the late stages of the Caledonian nappe thrusting.

Observed thrust kinematics and penetrative retrogression at the bottom of the Nakkedal + Tromsø Nappe Complex suggest that its final exhumation took place during prograde metamorphism of the underlying Balsfjord Series. The ongoing dating of the prograde metamorphism in the Balsfjord series will provide important information about a possible continuity between the timing of peak metamorphism in the Nakkedal + Troms $\varnothing$ Nappe Complex, the Balsfjord series and the underlying RNC. 